\title{
'Mountain Crown': Late Blight and Tomato mosaic virus-resistant Plum Hybrid Tomato and Its Parent, NC 1 Plum
}

\author{
Dilip R. Panthee \\ Department of Horticultural Science, North Carolina State University, \\ Mountain Horticultural Crops Research and Extension Center (MHCREC), \\ 455 Research Drive, Mills River, NC 28759-3423
}

Additional index words. crimson, $\mathrm{og}^{\mathrm{c}}$ gene, $\mathrm{Ph}-2$ gene, $P h-3$-gene, $S w-5$ gene, $T m-2$ gene

\begin{abstract}
'Mountain Crown' is a fresh-market plum tomato $\mathrm{F}_{1}$ hybrid (Solanum lycopersicum $\mathrm{L}$.) developed by crossing NC $30 \mathrm{P} \times \mathrm{NC} 1$ Plum. It is resistant to verticillium wilt (Verticillium dahliae Kleb) (race 1) (Ve/Ve gene), fusarium wilt (Fusarium oxysporum f.sp. lycopersici (Sacc.) Snyd. and Hans.) (races 1 and 2) (I/I and $I-2 / I-2$ genes), late blight (LB) $(P h-2 / p h$ 2 and $P h-3 / p h-3$ genes), Tomato mosaic virus (ToMV) (Tm2/tm2 gene), and Tomato spotted wilt virus (TSWV) (Sw-5/sw-5 gene).
\end{abstract}

\section{Origin}

'Mountain Crown', the $\mathrm{F}_{1}$ hybrid of $\mathrm{NC}$ $30 \mathrm{P} \times \mathrm{NC} 1$ Plum (synonymous with the name 12TMV001) (Fig. 1), resulted from a tomato breeding effort to develop a superior North Carolina-adapted $F_{1}$ plum hybrid tomato with early maturity, improved fruit color, and increased lycopene content based on the crimson gene in homozygous condition combined with fusarium wilt ( $I / I$ and $I-2 /$ $I-2$ genes), verticillium wilt ( $V e / V e$ gene), LB (Ph-2/ph-2 and $P h-3 / p h-3$ genes), ToMV (Tm2/tm2 gene), and TSWV (Sw-5/sw-5 gene) resistance. One of the parents, NC 30P, was released earlier for its superior horticultural traits and TSWV ( $S w-5$ gene) resistance. It is also resistant to fusarium wilt races 1 and 2 ( $I$ and $I-2$ genes) (Gardner and Panthee, 2010). Another parent, NC 1 Plum, was released for its LB ( $P h-2$ and $P h-3$ genes) and ToMV ( $\operatorname{Tm} 2$ gene) resistance through the North Carolina State University (NCSU) breeders release board and recently disclosed through the NCSU Office of Technology
Transfer (OTT). It is also resistant to fusarium wilt races 1 and 2 ( $I$ and $I-2$ genes).

NC 1 Plum resulted from selfing NC 10141, the $\mathrm{F}_{1}$ hybrid of NC714 × CLX38156, and selection from a large $F_{2}$ population (Fig. 1). NC714 is a large-fruited tomato breeding line with desirable horticultural traits developed by the North Carolina State tomato breeding program (Panthee and Gardner, 2011). CLX38156 is an unreleased tomato breeding line developed by HM-Clause Seeds. Seeds of this line were provided by the tomato breeder of HM-Clause to make crosses with NCSU tomato breeding lines as a source of ToMV resistance ( $T m-2$ gene). It is also resistant to LB ( $P h-2$ and $P h-3$ genes). The crimson gene in NC 1 Plum was derived from the NC 714 as well as CLX38156. The objective of the NC 1 Plum breeding program was to incorporate ToMV resistance ( $T m-2$ gene) to the desirable horticultural background of plum tomato. Single plant selections were made for large fruit size, yield, and other desirable horticultural traits in the $\mathrm{F}_{2}$ through $\mathrm{F}_{5}$ generations derived from selfing NC 10141. Seeds of the $\mathrm{F}_{6}$ generation were bulked to produce the $\mathrm{F}_{7}$ generation inbred line proposed for release as NC 1 Plum. This population is genetically fixed because no segregation of monitored traits was observed in the $\mathrm{F}_{4}$ or later generations.

\section{Description}

'Mountain Crown' was tested during observational trials at the Mountain Horticultural Crops Research Station (MHCRS),
Mills River, NC, in 2013-17, and in replicated trials in 2016 and 2017. When averaged over three replicated trials conducted at MHCREC in the summer seasons of 20162017, 'Mountain Crown' was equivalent to 'Plum Regal' (Gardner and Panthee, 2010) in total yield, marketable yield, marketable fruits (\%), and fruit size (Table 1). However, these measurements were higher during early yield (first three harvests), indicating that it matures earlier than 'Plum Regal' (Table 1). Results from replicated trials indicated that the yield performance of 'Mountain Crown' is highly stable in North Carolina and equivalent to other widely grown hybrids. 'Mountain Crown' is a main season hybrid that has the potential to replace the 'Plum Regal' hybrid, which is widely grown in North Carolina and other areas in the eastern and midwestern United States.

Fruit of 'Mountain Crown' develop a deep internal red color because of its crimson gene in homozygous conditions and are very firm, even in the fully ripened stage. This cultivar features fruit with three locules in most cases, providing excellent firmness. Immature fruits have a glossy, uniform green color ( $u$ gene), and the fruit pedicels are jointed. The fruits are cylindrical, with extremely smooth blossom end scars, and they have good resistance to fruit cracking and weather check. The flavor of 'Mountain Crown' has been wellrated during subjective taste evaluations at research station plots and by growers and consumers of fruits produced and marketed from grower trial plantings.

The plant growth habit of NC 1 Plum is vigorous and determinate, with attractive, heavy foliage cover. Fruit are smooth, slightly round in shape, have a nippled blossom end ( $n$ gene), and have jointed pedicels. Immature fruit have a uniform light green color ( $u$ gene). Ripe fruit are firm and develop a bright red exterior color and interior color as a result of the crimson gene. Disease resistance includes verticillium wilt $(V e$ gene), fusarium wilt races 1 and 2 ( $I$ and $I-2$ genes), LB ( $P h-2$ and $P h-3$ genes), and ToMV (Tm-2 gene).

The average fruit weight of NC 1 Plum during the three replicated trials was more than $86 \mathrm{~g}$. Because of its superior yield and good combining ability, it is being used as a parent in other crosses. NC 1 Plum is not intended for use as a cultivar; instead, it is solely used as a parent because of its
Received for publication 3 Sept. 2020. Accepted for publication 9 Oct. 2020.

Published online 10 November 2020.

The tomato breeding program of North Carolina State University was supported by the North Carolina Tomato Growers Association and the Hatch project of the USDA.

D.R.P. is the corresponding author. E-mail: Dilip_ panthee@ncsu.edu.

This is an open access article distributed under the CC BY-NC-ND license (https://creativecommons. org/licenses/by-nc-nd/4.0/).

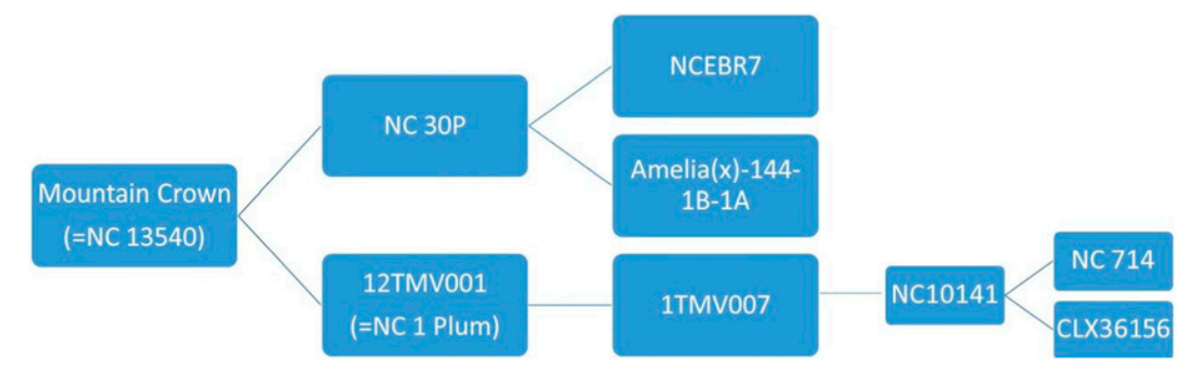

Fig. 1. Pedigree of 'Mountain Crown' hybrid tomato. 
Table 1. Overall performance of 'Mountain Crown' plum hybrid in replicated trials at Mountain Horticultural Crops Research and Extension Center at Mills River, NC, from 2016 to 2017.

\begin{tabular}{lccccccc}
\hline Genotype & ETY (ton/ha) & EMY (ton/ha) & Total yield (t/ha) & Marketable yield (t/ha) & Marketable (\%) & Fruit wt (g/fruit) & Disease resistance \\
\hline Mountain Crown & 39.4 & 23.5 & 101.7 & 72.7 & 71.5 & 115.8 & F1, F2, LB, S, T, V \\
Plum Regal & 23.7 & 18.6 & 104.0 & 70.7 & 68.0 & 122.2 & F1, F2, LB, S, V \\
LSD (0.05) & 5.1 & 3.4 & NS & NS & Ns & NS \\
\hline
\end{tabular}

$\mathrm{ETY}=$ early total yield; EMY $=$ early marketable yield; $\mathrm{F} 1$ and $\mathrm{F} 2=$ fusarium wilt races 1 and $2 ; \mathrm{LB}=$ late blight; $\mathrm{S}=$ Tomato spotted wilt virus; $\mathrm{T}=$ Tomato mosaic virus; $\mathrm{V}=$ verticillium wilt race $1 ; \mathrm{LSD}=$ least significant difference; $\mathrm{NS}=$ not significant.

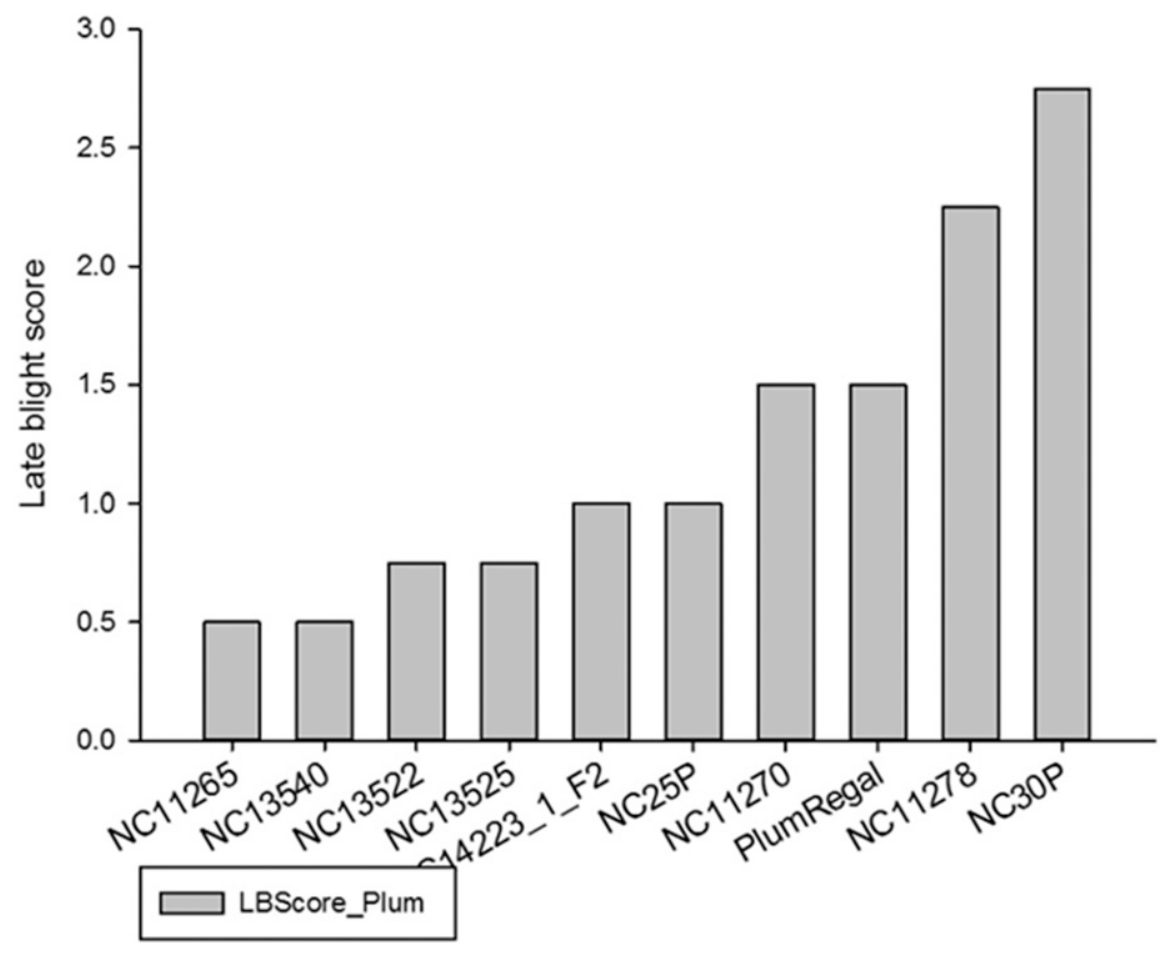

Fig. 2. Level of late blight in 'Mountain Crown' ('NC13540') during the late blight trial at Mountain Research Station, Waynesville, NC. 'Mountain Crown' was one of the most resistant compared with the other hybrids. The $P h-3$ locus is homozygous in NC25P and heterozygous in 'Plum Regal'. Late blight was scored using a scale of 0 to 5 , where $0=$ no late blight infection at all, $1=$ less than $20 \%$ plant surface covered with late blight, $2=21 \%$ to $40 \%$ plant surface covered with late blight, $3=41 \%$ to $60 \%$ plant surface covered with late blight, $4=61 \%$ to $80 \%$ leaf area covered with late blight, and $5=81 \%$ to $100 \%$ plant surface covered with late blight or dead.

contribution of excellent fruit size, the crimson gene, and other desirable horticultural traits and disease resistance genes when used as a parent for $\mathrm{F}_{1}$ hybrids. NC 1 Plum is the first line developed for release from the NCSU tomato breeding program that combines ToMV resistance and LB resistance into the desirable horticultural background along with the crimson gene. It is intended for crossing with other lines with the recessive crimson gene so the resulting hybrids will be homozygous for crimson and express an improved red color and increased lycopene content.

\section{Uses}

'Mountain Crown' has a vigorous determinate growth habit ( $s p$ gene) and foliage providing adequate cover for fruit protection. 'Mountain Crown' has resistance to verticillium wilt (Ve gene) caused by Verticillium dahliae Kleb., fusarium wilt resistance (I, I-2 genes) to races 1 and 2 caused by Fusarium oxysporum f.sp. lycopersici (Sacc.) Snyd. LB ( $P h-2$ and $P h-3$ genes) and Hans., resistance to ToMV (Tm2 gene), and TSWV ( $S w-5$ gene), which is contributed by an NC 1 Plum parent. When many hybrids with different gene combinations were evaluated for LB resistance at Mountain Research Station, Waynesville, NC, during Summer 2017, 'Mountain Crown' was one of the most resistant hybrids (Fig. 2).

\section{Availability}

We plan to license 'Mountain Crown' to a private seed company on an exclusive basis for seed production and sales. It is expected that commercial seed should be available in 2022. Distribution of seed of NC 1 Plum to other breeders requires a signed material transfer agreement, which can be downloaded from the following website address: http:// www.mountainhort.ncsu.edu/programs/tomato/ releases/tomato-seed-transfer-agreement.pdf. Small trial samples of 'Mountain Crown' are available from D.R. Panthee (dilip_panthee@ ncsu.edu), MHCREC, 455 Research Drive, Mills River, NC 28759.

\section{Literature Cited}

Gardner, R.G. and D.R. Panthee. 2010. 'Plum Regal' fresh-market plum tomato hybrid and its parents, NC 25P and NC 30P. HortScience 45:824-825, doi: 10.21273/HORTSCI.45.5.824.

Panthee, D.R. and R.G. Gardner. 2011. 'Mountain Majesty': A tomato spotted wilt virus-resistant fresh-market hybrid tomato and its parents NC 714 and NC 1CS. HortScience 46:1321-1323, doi: 10.21273/HORTSCI.46.9.1321. 